\title{
THE END OF SINGING NATIONALISM AS CULTURAL TRAUMA*
}

\author{
Aili AARELAID-TART and Anu KANNIKE
}

Institute of International and Social Studies, Tallinn Pedagogical University, Estonia pst 7, 10143 Tallinn, Eesti; aarelaid@iiss.ee, anu@iiss.ee

The article analyses how the Estonian Singing Nationalism as a counter-cultural system of values that served to protect national identity lost its raison d'être after the restoration of independent statehood, consequently bringing about the need for a substantial mental "inventory" and re-estimation of the Soviet past. This sudden and painful conflict where old values collide with a turbulent inflow of new ones is interpreted as a Cultural Trauma. By applying P. Sztompka's typology of reactions to cultural trauma and A. Hirschmann's exit-voice model, the authors outline four groups each employing different strategies for coping with the traumatic loss of the Singing Nationalism. The necessity of coping with the crumbling of former identities created a novel assessment of folk cultural activities, relating it with some fresh concepts of Estonian national identity in the global era.

\section{INTRODUCTION}

In Eastern Europe the 1970s and 1980s laid a foundation to many national liberation movements that eventually developed into large-scale protests, ultimately resulting in the collapse of the Soviet Union. The central value-constellation of the national dissatisfaction of Estonians is henceforth referred to as Singing Nationalism $(\mathrm{SN})^{1}$. It was similar to such social mobilizations as the Polish trade unions, the Hungarian green movement, Czech human rights organizations etc. The special feature of the Estonian counter-cultural movement, derived from its basis in the traditions of folk culture, was an abundant use of artistic codes. Artistic mobilization against totalitarian systems has also occurred elsewhere in Europe, e.g. the poetry festivals of the Catalans as a collective mobilization ${ }^{2}$

\footnotetext{
* The research has been carried out under ESF Grants No. 3171 and 5950.

1 For details on Singing Nationalism see p. 7.

2 Johnston, H. Tales of Nationalism. Catalonia, 1939-1979, 1991.
} 
against the Franco regime, or the Sámi Silent Resistance ${ }^{3}$. The collapse of Socialism inevitably brought along a major challenge to such collective mobilizations, as their historical task was fulfilled. Tens of thousands of people faced a situation where a model that had worked for years and had become totally routine suddenly became useless. Of course, it was painful and difficult to relinquish it, which lead to a traumatic departure. Something like an after-Socialist hangover took place ${ }^{4}$. People had got accustomed to a system of attitudes and values rooted in the experience of many generations, thus turning into their "own", even dear to their hearts. It was no longer necessary to defend this oppositional "own" against anybody, since the Soviet "alien" had ceased to exist. As a result, the SN that in Soviet Estonia had largely become synonymous with national identity ("The Estonians are a singing nation", "Our famous song festival tradition keeps us together" and other verbalizations of this assessment), started to lose its value rapidly.

\section{REASONS FOR THE OUTBREAK OF CULTURAL TRAUMA}

All of a sudden the SN was no longer necessary, but the path of innovation seemed unknown and risky. To analyse the radical and dangerous Post-Socialist change of identity, we apply the theory of cultural trauma (CT) as a theoretical framework. It is a relatively new paradigm introduced into the social sciences only over the past decade. ${ }^{5}$ The CT theory emphasizes that under very rapid social changes (wars, coups d'état, economic or natural disasters etc.) societies experience clashes between different value-constellations, which ends in serious adaptation difficulties for the majority of people. Of the basic human behavioral fears, listed by F. Riemann ${ }^{6}$, the two that become unleashed in a situation of CT are the fear of crucial change and the fear of losing identity. The attitudes developed earlier are usually considered to be one's "own" while the collection of newly emerging values and behavioral patterns are regarded as "alien". P. Sztompka interprets CT as a situation where the traditional values clash with some "alien" and incoherent ones. The most noticeable symptom of a condition conducive to trauma is people

${ }^{3}$ Stoor, M. The Sound of Sámi Silence - Avoiding a Conflict in Public as a Strategy of Survival. Abstracts. Crossroads in Cultural Studies, June 29-July 2, 2002 Tampere, Finland. Series B: 40, 2002. Department of Sociology and Social Psychology University of Tampere, 134-135.

${ }^{4}$ Sztompka, P. Civilizational Incompetence: The Trap of Post-Communist Societies. Zeitschrift für Soziologie, 1993, 2 (April), 85-95.

5 Alexander, J. C. On the Social Construction of Moral Universals. The "Holocaust" from War Crime to Trauma Drama. - European Journal of Social Theory, 2002, 5(1), 5-85; Neal, A. G. National Trauma and Collective Memory. New York, 1998; Eyerman, R. Cultural Trauma. Slavery and Formation of African American Identity. Cambridge, 2001; Sztompka, P. Cultural Trauma. The Other Face of Social Change. - European Journal of Social Theory, 2000, 3(4), 449-466, etc.

${ }^{6}$ Riemann, F. Hirmu põhivormid: süvapsühholoogiline uuring. Tartu, 1999. 
talking and trying to do something about it. ${ }^{7}$ Thus, CT is a social discourse whereby people collectively look for ways or strategies of coping with the severe conflict between "us" and "them" and thereby through innovative practice dislodge the boundary marks of the existing identity.

The present analysis of CT discourse relies on empirical material that consists of a collection of biographies (interviewer: A. Aarelaid, N72) as well as a series of focus-group interviews with some of the animators of folk culture (carried out in 1998, N14; 2003, N18).

CT discourse is one of the strongest self-reflexive and self-shaping expressions of the culture-carrier. It contains the dialectics of continuity and interruption, which are needed to simultaneously change and strengthen the national identity. A need to reorganize one's cultural space and memory is actualized in such periods where the normal development of culture is strongly disturbed and any further directions of development are often hard to predict. The politically successful restoration of independent statehood in Estonia in 1991 brought along a demand for a substantial mental "inventory" and the re-evaluation of the Soviet past, thus becoming a case of CT.

The long-lasting desire of the peoples of the former Socialist block was to be liberated from the Communist dictatorship. Several generations grew up during the Kremlin time. The hidden desire for freedom was rooted in the cultural memory of those people, acquiring the form of certain ideals and practices that were transmitted to many subsequent generations ${ }^{8}$. The few outbursts of anti-Soviet protest (Poland and Hungary 1956, Czechoslovakia 1968) met a bloody defeat and turned into clandestine value-constructions of a counter-cultural nature. The Estonian SN can be compared to the mission of the Catholic Church in Poland and Lithuania after World War II, as the latter was also formed over the course of decades and became a taken-for-granted counter-cultural system of values, protecting the national identity for the growing generations.

The conservation of pre-war nationalism in the Baltics and its transformation into a form of anti-Soviet collective consciousness is not identical with the straightforward dissident movements of Eastern Europe. As is generally known, the latter intensified soon after the Helsinki convention in the late 1970s, and mainly carried a political message (violations of human rights, brutal occupation of independent nations, etc.). Only small informal groups who were directly opposed to the official public sphere were connected with the dissident movements. A wider, nationallevel resistance was more informal and vague, as it was partly put up in the private sphere. In the Socialist system the "informal and formal spheres were completely mutually exclusive. What was allowed to be expressed in one sphere was - almost

7 Sztompka, P. Op. cit., 456.

${ }^{8}$ Kannike, A. Kodukujundus kui kultuuriloome: moe ja traditsiooni dialoog. - In: Kultuuride dialoog. Acta Universitatis Scientiarum Socialium et Artis Educandi Tallinnensis, Humaniora, A20. Ed. A. Aarelaid-Tart. Tallinn, 2001, 143. 
automatically - perceived as non-valid in the other". ${ }^{9}$ At the same time the opinionmobilizations connected with the historical traditions of national cultures were formed in a social reality that is defined as the private-public sphere. "In contrast to the "second society" the "private-public" sphere did not have the character of an exclusive field of communication within a particular social milieu." of the Estonian SN manifested visibly in the sovietized public sphere; its infrastructure was even financially supported by the state. To glorify the Communist Party and Marxism-Leninism, ten nationwide Song Festivals were organized by official institutions in the period 1947-1990. At the same time the common folklorebased activities within the Estonians' private communication circles had a clearly anti-Soviet coloring. Thus, singing and dancing together in a perfectly traditional style was a social phenomenon that vividly reflected the existence of double mental standards so typical of the Soviet society. As such it had become an organic way of national existence and part of the biographies of different generations. The following extracts from biographies illustrate how Estonians interpreted choir singing and folk dancing as purely anti-Soviet activities in their lives.

Man, b. 1936: After the Hungarian events the tradition of student caps was gradually restored. At first choirs got caps. I sang in a male choir. These were totally national-minded organizations. At all our meetings we sang prohibited songs, discussed the Estonian cause. As an encore we sang "My fatherland, my pride and joy" and "I was told in my childhood...", that is, the songs that were removed from the official repertoire of the song festival. $^{11}$

Man, b. 1946: My career as a folk dancer started already in Tallinn Secondary School No. 46 under the supervision of Alfred Raadik and lasted all through the university and even longer... It was a form of social experience that trained both body and soul. The body - just to be in good shape, dancing was an alternative to sports. The soul - to enjoy oneself, and I guess that there was more than enough Estonian-ness in it. We went to folk dance festivals in Estonia and the Baltic "Gaudeamus" festivals, everywhere there was our own Estonian folk dance, we felt that we were Estonians through and through even when we danced Russian dances. Folk dance has, indeed, been a serious form of transmitting Estonian nationalism. ${ }^{12}$ Woman, b. 1959: It was just the Finno-Ugric mentality that we opposed to the imperialist ideology. I sang with several friends in the folk ensemble "Hellero". With this ensemble we made numerous trips to Russia, to meet other Finno-Ugric peoples. These trips strengthened our identity as Estonians, and we clearly opposed that to the surrounding political reality ${ }^{13}$.

\footnotetext{
9 Oswald, I., Voronkov, V. The "Public-Private" Sphere in Soviet and Post-Soviet Society. European Societies, 2004, 6(1), 107.

10 Ibid.

11 Authorized translation from Aarelaid, A. Ikka kultuurile mõeldes. Tallinn, 1998, 146.

12 Ibid., 181.

13 Ibid., 228.
} 
Being realized in the public-private sphere, the $\mathrm{SN}$ acquired a habitual character and involvement in choir singing or folk dancing was considered an important factor in children's upbringing. State support for such activities was self-evident. People developed a habit - even while singing Soviet repertoire - of thinking about being an Estonian in the first place. Such an essentially double-faced constellation of values became a way of preserving one's identity during the four Soviet decades. In private it manifested as an anti-Russian attitude, but for the official sphere one often behaved in a hypocritically Soviet-minded manner. The very concept of folk culture came to be limited to folklorism - mainly singing and dancing, and, to some extent, handicrafts in an ideologically censored and strongly stylized mode. Another example from a long-time patron of women's crafts illustrates how closely the penchant for protest and collaborationist attitudes were intertwined.

Woman, b. 1914: Women's crafts were in disgrace in the 1950s as a stale bourgeois phenomenon. In the 1960s pupils' exhibitions started to be organized and crafts based on folk art were once again praised. Masters of respective fields analyzed and evaluated the exhibitions. Exhibitions were arranged on the school level, regional level and republican level. The crafts of Estonian schoolchildren were also introduced at international exhibitions in Moscow and the Socialist countries and they were awarded medals. In 1967 a new campaign was started - 100 national souvenirs to friends from the sister republics on V. I. Lenin's anniversary. ${ }^{14}$

Thus, for the SN, the CT provoked by the collapse of Socialism works on more than one level. The enemy against whom the counter-cultural value system was once built up is rapidly disappearing. Correspondingly, many of those who previously aspired for freedom become disoriented in their activities and feel deceived. The mass folklore movement ceases to be a phenomenon of the public-private sphere because the "social demand" for such a double game vanishes and interest in folklore has separate positions in the public and private spheres. The final rise of the "iron curtain" is accompanied by a massive influx of Western values as well as commercial culture. Against this background the former counter-cultural values no longer have the meaning they used to have. Thus, the end of the Socialist worldview inevitably brought about a sort of mental agony of its opponents that can be regarded as CT. In order to understand the dialectics of the triumph and the decline of the SN, we will continue with a brief examination of its history.

\section{THE UNRAVELING OF SINGING NATIONALISM}

The tradition of choir singing in Estonia was a direct loan from the German culture and the first Estonian Song Festival followed the model of the Baltic German song contests quite accurately. But from that time on the get-together

\footnotetext{
14 Ibid., 175.
} 
with singing songs and delivering speeches in Estonian was considered to be the self-creativity of a nation standing up against a dominating foreign upper-class atmosphere regarding the Estonians as second-rate country-people. Due to the impact of the first national song festivals the choral and orchestral societies became the most important Estonian cultural institutions throughout the final third of the 19th century. Continuous enlargement and renewal of those institutions helped the Estonians to establish themselves more and more as a separate nation, different from the foreign dominant power-groups of Germans and Russians. One could say that Estonians gradually sang themselves into a modern nation.

In the years of the independent republic (1918-1940) the tradition of song festivals was profoundly ritualized as a patriotic event. The Estonians were proud of having that kind of a nationwide feast intended for declaring their identity and solidarity. Thousands of local singing and dancing societies were interpreted as institutions defending national sovereignty. The song festival itself was seen as a regular manifestation of cultural self-being. "Not only was new choral and orchestral music needed for the festivals themselves, but increasingly the best works from all musical genres were presented during concerts coinciding with the national song festival." 15

In the 1940s, after the occupation of the Republic of Estonia by the Soviet forces, a process began that could be called the conservation of nation-building. The normal course of developing the institutions necessary for the functioning of a nation-state was interrupted. As Estonia was too small to take up arms, only a peaceful way of resistance was conceivable. Thus, traditional folk culture played an enormous role in the process of consolidating indigenous Estonians under the rule of a Communist-Party state and operating as a semi-legal alternative structure for maintaining national identity. Ironically, every kind of amateur art and folklore activity was encouraged by the totalitarian state. Seizing that restricted legitimacy from one side, and a huge state financial support from the other, the Estonians built up a unique phenomenon in their cultural field - the Singing Nationalism. Namely, the Estonians managed to convert their historical tradition of song festivals, officially allowed by Moscow within the boundaries of amateur folklore activities, into an original nation-wide protest movement. ${ }^{16}$ The grand event of the Song Festival taking place every five years (with 30, 000 singers, 10, 000 dancers, more than one hundred thousand spectators) was transformed into the keyevent carrying and defending the national identity of indigenous Estonians. The establishing of local choirs and folk-dance groups (some 4000 in all with 60, 000 participants, or every 15th Estonian) was regarded as a vital activity, all the more as there was state financing for these. The learning of folk songs and folk dances, the sewing of folk-costumes, the organizing of local one-day singing festivals and regional singing competitions etc. acquired a disproportionate magnitude and grew into a specific form of social mobilization. The processions and two-day concerts

15 Raun, T. Estonia and Estonians. Stanford, 1991, 37.

16 See: Kuutma, K. Laulupidu kui kodanikualgatuse erivorm. - In: Kodanikualgatus ja seltsid Eesti muutuval kultuurimaastikul. Ed. A. Aarelaid. Tallinn, 1996, 39-48. 
of the Song Festival turned into anti-imperial political demonstrations, regardless of the ever-present attempts to steer the repertoire of these festivals towards something more in accordance with the Communist ideology.

Such support for the Estonian national identity could be interpreted as "the Otherness" from the point of view of the Soviet ideology declaring that culture ought to be "national in form and Socialist in content". The Singing Resistance as an opposing partner could not exist as an independent cultural phenomenon. On the contrary, it could become real only by accepting the severe and inflexible dominant culture that aimed to mix national self-being into the "melting pot" of a "unified Soviet nation". The Singing Resistance was a "carnivalesque" dialogue between two opposite value-systems that had a common contextual background binding them together like Siamese twins. It converted the dominant ideological paradigm into a cynical version of "Socialist in form and national in content".

During the Soviet period the tradition of song festivals was simultaneously reproduced on the central stage and on the backstage. On the central stage or public sphere level ideological correctness was continually tested. For this purpose a new element was introduced into the Estonian song festival tradition: all the various choirs had to jointly perform a cantata praising the Soviet regime and party initiatives. On the backstage level, or private sphere "good old" Estonian symbols, for instance emblems with cornflowers, were displayed and songs from the Awakening Era were performed in order to follow the historical trail of national identity. The dialogue between the two voices concurrently coming from the central stage and backstage created an ambivalence that allowed the opponents, although officially denying each other's existence, to live together.

A very important event revealing the nature of the public-private sphere was the festival procession where all the participants (about 30,000) marched on a ritualized trajectory from the central Victory Square to the Song Festival Ground, about 4 kilometers altogether. Officially it was organized according to the patterns and rhetoric of the May and October demonstrations. People carried slogans glorifying the "might, wisdom and greatness" of Lenin, Stalin and the Communist Party in expressions like "Under the banner of Lenin, under the guidance of Stalin, onward to the victory of Communism!" ${ }^{17}$ At the same time all participants of the procession wore the national costumes of their native counties to manifest local as well as nationwide identity. The thousands of lookers-on hemming the streets stimulated the participants with nationalist greetings like "Welcome to the brave Estonian men!" or "Long live the Estonian singing tradition!" or "Long live the nice Estonian girls!" etc. This wide discrepancy between written and oral slogans, official and unofficial texts was obvious and ironical; everybody who was able to understand this ambivalent game enjoyed it ardently. The Festival Ground was perceived as a sacred place where Estonians from every county and parish would meet to express their national solidarity. The moment of singing the unofficial

17 Zdravomõslova, E., Temkina, A. October Demostrations in Russia: From the Official Holiday to a Protest Manifestation. - In: Temkina, A. Russia in Transition: The Case of New Collective Actors and New Collective Actions. Helsinki, 1997, 140. 
anthem of these festivals, the song "My fatherland..." by G. Ernesaks (first performed in 1947), was interpreted as a ritual manifestation of national protest against the Soviets, against Russification, against foreign pressure. Although from time to time this song was excluded from the official repertoire, it was always sung, and the audience was captured by euphoria, people laughed with tears rolling down their cheeks.

The years 1987-1991 marked a transition period of the national liberation struggle, when broad-based popular movements and restitution-oriented patriotic organizations (the national heritage protection movement, students' fraternities, the Women's Society, the Male Choir Society, etc.) called for the restoration of pre-war independence. This unique period in Estonia is known as the Singing Revolution, as it was based on the familiar traditions of song festivals. In this period of open struggling for independence, which began in 1987 with a campaign against the use of phosphorite mines in Estonia and culminated with the coup d'état of 1991, the previous institutions of cultural resistance transformed into large, active and victorious social movements. Different cultural practices like amateur folk-music and folk-dance groups or art and handicraft studios, local studies groups and nature conservation societies utilized the organizational capital gathered during the long Soviet period. The Estonians reshaped the institutional structure of this cultural capital and turned it into political capital ${ }^{18}$. Based on the song festival tradition as the institutional structure of an ethnocentric counter-culture, they established an open set of politicized institutions serving in the struggle for national independence within just a few months. The same persons who had earlier participated in the above groups now incited people to take part in the Singing Mass Protest Actions in June 1988 and in the formation of cells of antiSoviet organizations like the Popular Front and Estonian Citizens' Committees.

After the independent statehood was restored, the Popular Front organized a mass meeting at the Song Festival Ground to glorify FREEDOM. At this meeting people once again joined their voices to sing their favourite songs from the traditional choir repertoire as well as some new songs that had been created in the years of the Singing Revolution, and delivered festive speeches full of national pathos. However, this also marked the end of the Singing Revolution and SN had to start looking for a new face.

\section{TRAUMATIC DECONSTRUCTION OF SINGING NATIONALISM}

$\mathrm{SN}$ as the primary arena for folklore activities had developed in a closed society and attempts to conserve it in a society that was opening up actually provoked moments characteristic of CT. These include the old values conflicting in a sharp and painful way with a turbulent inflow of a new and unknown value

18 In the sense of P. Bourdieu. 
constellations. The construction of identity that had been built on the SN was relatively mono-structural (predominantly carried by folk culture groups). As such it was well suited for a small and economically not very differentiated nation. A result of the annexation was that a non-Estonian community constituted nearly two fifths of the population, settling in the historical territory of the ethnos. This is also important from the point of view of the SN. The world of folk costumes, folk festivals etc. remained a refuge for the Estonians to which the Russians had no access. To some extent such ethnic resistance also included an opposition of the countryside and the cities. The majority of Estonians were still connected with the countryside and folk traditions, but the foreign labour that had poured into towns often represented a migrant culture without solid roots. Such had been unknown in Estonia until then. The Estonian-Russian cultural segregation that was part of everyday life was also part of the Singing Nationalism as a leading idea. Some quotes from biographies illustrate just that:

Man, b.1961: In our home the attitude was clearly different from the official ideology. Mother was Estonian-minded, father more collaborationist. At the same time father had been a "Finnish boy" (a voluntary in the Finnish army during WW II, - A.A.), already the military training teacher in high school had injected Estonian-mindedness into the boys. Now and then father would write some piece on the history of the Communist Party, calling it hackwork. An anti-Soviet attitude was obvious everywhere around me all the time; it was not active resistance, but a total style. Everybody was saying: "Don't jump around like a Russian!”, “In these clothes You look like a Russian!",19.

Woman, b. 1979: The defiance and revolt of my parents' generation against the enforced ideology was expressed in keeping the old traditions and heritage alive. ${ }^{20}$

In the enthusiastic mood of liberation it seemed natural at first that the myth of "singing Estonian-ness" should preserve and even grow. The nationalism built on the song festival tradition had, after all, 120 years of history behind it, and one intended to develop it further after the republic was restored (even a joint song festival of Estonian and American choirs took place). Before the start of the occupations in 1940 Estonia had clearly been a society of small farmsteads with strong patriarchal traits and no remarkable upper bourgeoisie, if one ignores Baltic German historical aristocracy. The majority of the population lived in villages and was engaged in small-scale agricultural production. One of the main forms of social networking were village societies that primarily cultivated activities based on folk culture. Under the conditions of the so-called Silent Era of the 1930 s, a mechanism of national propaganda was introduced that also praised national handicraft, especially the making of folk costumes, home decoration, choir singing and folk dancing as important values and activities.

19 Aarelaid, A. Ikka kultuurile mõeldes, 230.

20 Kannike, A. Kaks põlvkonda, üks rahvakultuur. - In: Rahvakultuur ingliska ja internetiga. Ed. A. Aarelaid. Tallinn, 1999, 55. 
After the restoration of independence in 1991, nostalgic idealism was widespread. One dreamed that small-scale farming would be restored, while every Estonian would share the enthusiasm for song festivals and the state would subsidize nationally minded societies. This was a distinctive case of Post-Socialist nationalist euphoria characteristic of the whole Eastern Europe, accompanied by the mushrooming of political parties grounded on national ideals. However, such an idealistic vision of folk culture and national future was not to last very long.

Post-socialism in Estonia was accompanied by large-scale re-privatization, the official dissolution of collective farms, the establishment of a liberal trend in economy and a fragmentation in party politics. Besides a rapid outburst of economic initiative, social inequality quickly started to develop. The infrastructure set up for the reproduction of folk and youth cultures during the Soviet period (local clubs of collective farms and trade unions, pioneers' houses, children's hobby groups or hobby schools etc.) started to languish. The salaries of cultural workers grew much slower than in other professions. The low income of the population introduced the requirement for longer working days and thereby minimized the free time available for participation in social life. Thus, involvement in folk culture was hindered by lack of time, money or place and thus the SN was deprived of its material basis. To illustrate these developments, here are some extracts from interviews with people who were actively involved in folk culture. ${ }^{21}$

The cultural director of a parish: I come from a coastal area where, thanks to the last ten years, such a change has taken place that big fishing collective farms have disappeared and also such big Soviet-time machines that financed culture. Previously everything was free - folk costumes and instructors. Then all this died out. And those miserable folk costumes are still used in some places. There was a long dispute over who would get those costumes. Now the parish commune tries to solve the problem and take measures to preserve them. Societies are being revived once again, they come together because they need such gathering, they do not get paid now and people hardly come to events if they have to pay (interview of March 10, 1999).

A cultural worker from Pärnu: For example in the town of Pärnu all the groups of ELO (Estonian Children's Organization, formed on the basis of the former Pioneer Organization - A.A.) were dissolved with a decision of the Council of Headmasters, and the children who had had something to do before that, remained unoccupied. Now elsewhere in the republic these ELO children are active again, in Raeküla school it is being restored, some children were sent to study in Tallinn, but all this takes time. Secondly, all the financing of school hobby groups was taken away, it was told that they would go to the Pupils' House together - but there is room only for a handful of children there. Schools should be full of circles in the evening, but they are not. This really breaks my heart (interview of April 14, 1999).

21 In 1998-1999 15 focus group interviews were carried out, see also: Aarelaid, A. Rahvakultuuri piirid määrab dialoogisuutlikkus. Kogumik: Kultuuride dialoog. Acta Universitatis Scientiarum Socialium et Artis Educandi Tallinnensis, Humaniora, A20. Ed. A. Aarelaid. Tallinn, 2001, 117. 
After the Republic of Estonia was re-established in 1991, a certain lustration of the SN began. Alongside with an active negation of the whole Soviet past one also questioned the existence and meaning of the resistance culture of the 1970s and 1980s. Some circles started stressing the collaborationist character of the Soviet-time song festivals. Quite a considerable part of the youth of the early 1990s looked at folk culture with a shrug and regarded dancing enthusiasts as freaks: "singing under the Song Festival arch seems like artificial resuscitation of an ancient dinosaur." 22 The young generation embraced the cultivation of one's body - fitness, aerobics, weight watching etc. Folk culture came to be seen as a hobby of those who did not have enough money to pay for "sensible" things.

The exclusion of Russians as "aliens located beyond the boundary" 23 was a clear value orientation of the SN. However, building up a new independent statehood ethnocentrically proved to be painful for Estonians. International organizations looked at the foreigners who had arrived here in the occupation years as minorities needing protection. In Estonia, like in Latvia, the majority of Russians who had arrived here after 1944 could not speak the language of the local people and regarded studying it with uncaring superiority. This proved unexpectedly favourable for building a resistance culture as in most cases the "dumb" Russian clerks just failed to understand the bursts of nationalism based on the Estonian folk culture. However, as the reconstruction of independent statehood began, the OSCE and other relevant organizations started to demand that the 900,000 Estonians ought to integrate the 600,000 non-Estonians quickly into a young democracy, and additionally set up a massive instruction course for the "foreigners" to study the sacred mother tongue of the aboriginals. Thus the Estonian state passed an integration program and received money for this from European support foundations. Trying to carry out such an enormous task meant breaking the national criteria of identity associated with the SN. The following quote from a newspaper represents an extreme example of the painful identity-related outburst of the Estonians.

Every nation has its own culture. The problem is that the specimens of homo soveticus who are the strongest opponents of our way as well as other democratic ways of development, have grown up and still live in a so-to-say outside culture. They either have not had or no longer have a connection with their own national culture, they either have not had or do not yet have a connection with the Estonian culture. They even cannot recognize it as a basis. Living without cultural connections, they do not understand what is proper or improper, beautiful or ugly. Of course they feel bad, because of the void in their souls. For children it is even worse. We know that such kind of anxiety can grow into apathy or aggressiveness. We probably ought to help these people to find themselves. Either they go on raging with the price of self-destruction, or return to their homeland, to

22 Kannike, A. Kaks põlvkonda, üks rahvakultuur, 58.

23 On exclusion of foreigners as a typical strategy of ethnic defence, see: Dictionary of Race, Ethnicity \& Culture. Eds. G. Boloffi, R. Bracelenti, P. Brahman, S. Gindro. London; New Dehli, 2003,70 . 
their relatives and cultural and social connections, or they start building a new home in Estonia in a constructive manner. What could be a fourth option? To subjugate Estonians in their fatherland, establish new slave camps to exterminate the dissidents $?^{24}$

Besides infrastructural and ethnopsychological factors, the consumer culture that struck the Estonians without their participation in importing it, appeared as a powerful challenge to the SN. Due to a neighbourhood of countries with very high living standards and the eagerness of foreign investors, the Estonian market was quickly filled with all sorts of trendy goods and services. Although many people still cannot afford them, they have provoked a fierce competition of value attitudes. Home-knitted or crocheted jackets face a tough competition with prestigious brands, local choirs compete with an endless stream of CD-music. But as handicraft and thereby the continuation of the national substance are still seen as possessing a certain value, such rivalry is, for the time being, viable.

Librarian: I am one of those children whose hobbies used to be choir singing and folk dancing. For me, this actually was the whole folk culture. Now when I have travelled around more, it seems to me that it was kind of a campaign. When we had Soviet power and the iron curtain - then namely that helped us to remain Estonians. Today I rather understand folk culture as what has been transmitted from mouth to mouth and from hand to hand inside the family, because there are very few families where nobody would wear ornamented gloves, socks knitted by grandmothers or home-knitted woolen jackets. This has been regarded as very self-evident that I have a piece of clothing woven by hand, maybe even made of the wool of my neighbor's sheep. That is folk culture, plus the old tales that our grandparents and parents have told us. Things are not hopeless (interview of February 9, 1999).

Thus, the SN that through many generations had become a synonym for folklore-based self-initiative, and that clearly functioned as a national protest culture, gradually became incongruent with itself. There appeared a need for separating the political, economic and tradition-keeping aspects of the folk culture. This process can be also regarded as deconstruction of the SN.

\section{STRATEGIES FOR COPING WITH THE TRAUMATIC LOSS OF THE SINGING NATIONALISM}

There are several ways how the Estonian society reacts to the CT. The essential difference from the Soviet period is that people are facing fundamental changes that encompass not only the folk culture but also the whole contextual system of its functioning. Further on it will be analyzed how the CT is expressed

24 Quoted from: Nugin, R. Meedias kajastuv eestlaste mina-pilt 1991. ja 2001. aastal. - Acta Historica Tallinnensia, 2003, 7, 170. 
in the discourse of particular groups engaged in folk culture. This demonstrates how different groups use folk heritage for maintaining their national, group and individual identities and how they construct different versions of the folk culture model to overcome the situation of identity crisis.

The various manifestations of the CT are closely connected with alternative and conflicting concepts of the past and visions of the future. At the same time the ways of coping with the CT depend on the range of possible communication partners and also how open to dialogue the different segments of society actually are. By applying R. Merton's typology of adaptations to anomic conditions, P. Sztompka describes four common strategies that are applied in reaction to a cultural trauma: retreatism, ritualism, adaptive innovation and cultural rebellion. ${ }^{25}$

The coping strategies can also be considered within a general framework of the "exit-voice" model described by A. O. Hirschmann. When speaking about the dysfunctional behaviours of any economic, social or political system and organizations in general, he argues that the society must be able to marshal from within some forces which will make as many as possible of the faltering actors to revert to the behaviour required for its proper functioning. ${ }^{26}$ Hereby two alternative but mutually connected strategies dominate: the exit option - leaving the system; and the voice option - expressing dissatisfaction to authorities, general protest. ${ }^{27}$ The proportion of the two options used in a community depends on the population's general readiness to complain and on the availability of such institutions and mechanisms that can effectively communicate these complaints.

By combining the above-mentioned two classifications and observing the strategies for coping with the CT, one could delineate certain groups that have come into being due to the fall of the SN as a mass-protest activity in Soviet Estonia. We can see that in many cases retreatment and resistance, on one hand, and resistance and innovation, on the other, appear as two sides of the same coin. These are contrasting, but not mutually exclusive categories. Hirschmann notes that voice is a far more "messy" concept because it can be graduated, all the way from faint grumbling to violent protest. ${ }^{28}$ Thus, the polyphonic nature of "voice" is also reflected in the typology of these groups, evidently according to their coping strategies.

\section{Exit - Retreat group}

Retreatism is a strategy that characterizes the behaviour of groups that are strictly oriented to national tradition, usually uniting people of the elder generation. The groups that identify with orthodox concepts of folk culture see all the changes that took place in the 1990s as negative ones. Their activities aim to reproduce

25 Sztompka, P. Op. cit., 461.

26 Hirschmann, A. O. Exit, Voice and Loyalty. Responses to Decline in Firms, Organizations and States. Cambridge, Massachusetts, 1970, 1.

27 Ibid., 4.

28 Ibid., 16. 
folklorism in the purified sense of the word, regarding collectivity as superior to individual creativity. The narrative of a paradise lost dominates the rhetoric of this group.

I still remember so clearly when we used to sit together in the evening. There was no electricity yet. Then we sat in the twilight. Sometimes the women carded wool. Chicken-plucking bees were very popular among us. Then we had all sorts of dung-carting bees, wool-carding bees - that is, all sorts of bees. Later all the young people spent time together, playing... That's what real folk culture is like. ${ }^{29}$

Their concept of national culture is one of a temporally and territorially limited phenomenon the "purity" of which has to be conserved. This attitude is relatively close to the official image of Estonian-ness - both in the Soviet period and now with folk culture fulfilling the function of representation and prestige. One's attitude to present-day realities is passive, and a rigid carrying-on of the traditions is seen as a positive scenario for the future. The solution for overcoming the crisis is considered to include a constant inflow of state subsidies in order to keep the old structures and the mechanisms of massive folklorist education and propaganda going. The usual keywords of this group are "support" and "preservation". Here, cultural trauma is verbalized from the position of a victim who needs compensation. There is a constant re-dramatization of negative events and distrust of any innovations.

A similar approach is articulated all over the former socialist block. The case of Poland, for example, has been described as follows: "The chase of profit and idolatrous function of money destroy unselfish artistic activity of numerous folk artists and unpaid hobbyist activities of the organizers of spontaneous cultural life. The activity of cultural and folklorist associations is declining... Moral norms, regulating people's natural relations and sanctioned by folk culture traditions, cease to be valued. Social pathology, like alcoholism and drug abuse, prostitution and terrorism take over everywhere at a quick pace." ${ }^{30}$

\section{Exit - Ritualization group}

A ritualistic reaction would mean turning or returning to established traditions and routines of the $\mathrm{SN}$, cultivating them as safe hideouts from where to deflect cultural trauma. ${ }^{31}$ In the present-day Estonian state ritualization has a nationwide centerpiece in the song festival that was recently included in the UNESCO list of world heritage. It is a first-rate symbolic event and a cultural priority of the state.

29 Aarelaid, A. Rahvakultuuri piirid määrab dialoogisuutlikkus, 113.

30 Marczuk, M. Threats to the Folk Culture in Central Europe in the Process of Transformation, and Attempts to Overcome Them. - Selected Papers of the International Conference "Folk Culture at the Beginning of the 3rd Millennium: New Challenges and Means of Support" 6-10 June 2001. Vilnius, 2001, 3.

31 Sztompka, P. Op. cit., 461. 
In the Estonian society not long ago there arose a discussion about the meaning and future of the song festival tradition. Although it is still an important event for many local choirs and dance groups, it cannot be claimed to be a universal national symbol any more. Liberal-minded politicians and businessmen are of the opinion that the state should not subsidize a hobby of a few that is becoming more and more marginal. Among the younger generation opinions are divided: some look at the ritual with irony, whereas some others consider it worthy of being preserved.

Besides the song festival, representative and governmental organizations are interested in other major successful projects that offer prestige value in the international arena for the state. Therefore, those local projects that are led by (former) professionals have a much greater chance to win state support. These activities usually belong to mainstream folk culture, while alternative ideas or projects presented by "unknown" leaders have to face a tougher competition.

\section{VOICE - RETREAT-RESISTANCE GROUP}

Quite frequent in Estonia are voices of resolute resistance to all new cultural processes accelerated by the changes of political regime and the transition to market economy. The people who articulate such a general resistance largely coincide with the group whose reaction type falls under retreatment. Earlier it was an absolute cultural norm in Estonia to recruit the next generation for the same kind of folklore or other traditional associations. Now an interruption in the social heritage has taken place - the younger generation has refused to continue these activities in the same way. The elderly describe the young as lacking any interest in folk culture, passively adapting to mass culture and unwilling to co-operate. Actually some new factions have arisen among the younger people whose ideas are increasingly shared by this age-group. These young enthusiasts also emphasize a strong opposition to foreign influences. However, they are more active and regard new projects in the field of folk culture as an uncompromising mission, a positive alternative to the levelling tendencies. In their opinion, culture should not be developed according to business logic. ${ }^{32}$ This approach characterizes, for example, the Genuine Culture (omakultuur) movement and the half-professional or professional folk musicians who have graduated from the Viljandi Academy of Culture, the folk-life activists participating in the Native Place (Kodukant) movement and also the Institute of Rural Sociology at the Estonian Agricultural University.

The native-cultural development of Estonian statehood is possible only on the basis of the archetypes of a parish-centered peasant culture with its animated relation towards nature. For the Estonian elite suffering from an identity crisis the heritage of the indigenous population has no meaning... even in nature protection, eco-tourism and folk music we import values,

32 Barkalaja, A. Kuld hobusesõnnikuks, raha lepalehtedeks. - Eesti Päevaleht, 2004, 20. mai. 
knowledge and cultural products from every corner of the world. Even university-educated Estonians (intellectuals?) usually cannot recognize the genuine heritage of their people: just consider that "Õllepruulija" (originally a German folk song "The Brewer", widely sung in Estonia - A. K.) is believed to be an Estonian folk song! ${ }^{33}$

\section{Voice - Resistance group}

During the Soviet period the intrinsic meaning of folk cultural activities in Estonia was unambiguously directed against the dominant Communist ideology, yet now the option of resistance is used in multiple ways and on a larger scale than earlier. Theoretically, it can be said that while exit requires nothing but a clear-cut either-or decision, voice is essentially an art that is constantly evolving in new directions. ${ }^{34}$ Resistance aims at a transformation of culture in order to replace the traumatic condition with a completely new cultural setup. ${ }^{35}$ Some forms of resistance reveal unity with previous periods whereas some are inspired by the new social reality. The increasing segmentation of the Estonian society into different groups is also reflected in the diverse objectives of resistance. Contradictions between generations are especially remarkable. Hereby, two dominant layers of resistance can be outlined as they appear in the trauma discourse:

\section{a) resistance to mass culture and to the commercialization of cultural institutions}

The majority of people engaged in folk culture have realized that the spreading mass culture and commercialization in all spheres of life are inevitable. ${ }^{36}$ Most of the local cultural activists regard this as a reality that one has to cope with. They do not oppose mass culture as a whole, but they do oppose its domination and its effect of making people passive. In their everyday practice they do not give much thought to whether a certain phenomenon or event belongs to mass culture or folk culture, but their aim is to attract and activate local people.

During a round-table discussion with local culture activists it was a dominating viewpoint that in order to avoid the domination of mass culture, one has to find compromises.

The acuteness of this problem depends a lot on the local context. In small villages or more remote regions the competition for audience and active participants

33 Kasemets, A. Eesti pärimuskultuuri ja külaliikumise kasvamise teed XXI sajandil. - Eesti külade ja väikelinnade liikumise "Kodukant” III Maapäev Hiiumaal Käinas 29.-31.7.1999. Dokumentide kogumik, 24-25.

Aarelaid, A. Rahvakultuuri piirid määrab dialoogisuutlikkus, 100. 
is tough, and here mass culture is characterized as "suffocating". In medium-sized centers, however, resources available for developing a more diverse cultural life, different forms of culture are seen to exist peacefully side by side and folk-culture based activities are just one of a multitude among which one can choose. For example, "In Vigala, a rock festival and a traditional-style village swing party took place on the same day and the "hairy" enthusiastically mixed with the people in folk costumes" ${ }^{\prime 37}$. Compromises are considered to be a precondition if one wants to succeed in preserving the heritage: "If you have courage and brains, such things can be united. But you need tolerance. Mass culture has to be filtered." ${ }^{38}$ Here we can see that resistance is transforming into adaptive innovation as mass culture is gradually appropriated by using critical selection and by "recycling";

\section{b) resistance to the marginalization of folk culture}

This is a strategy most strongly articulated by the movements and groups promoting local (county, parish, and village) identity 39 . For example, the "Kodukant" movement sets among its aims "more equal relationships between the town and the countryside", "to return identity to the country people, to value rural products", "to shape public values in favour of the countryside". ${ }^{40}$ As life in the countryside has few reflections in the media and one-sided ones at that, it is considered necessary to "arouse the interest of the media with new ideas and enterprises; arrange press conferences, general discussions, acknowledge the best papers and journalists. ${ }^{, 1}$ Through local festivals, home-decoration and natureprotection campaigns people express their objection to the secondary status of the country-people, the whole country-life indeed. Although social and regional differentiation has been especially rapid and traumatic in Estonia, contradictions between the "cool" urban culture and the "dull" country-life are also evident elsewhere and local cultural initiative manifests in quite similar ways. The same resistance occurs elsewhere: in Finland, for example, ethnologists also characterize local festivals as "a temporal and ritual counter-attack to the marginalization of rural regions". ${ }^{4}$

37 Transcript of the discussion "Values and Society" at the Estonian Folk Culture Development and Training Centre, 21 Oct. 2003.

38 Ibid.

39 Aarelaid, A., Kannike, A. Mis on toimunud rahvakultuuris? - Eesti sotsiaalteadlaste aastakonverents IV, 24.-25. november 2003. Ettekannete ja teeside kogumik. Tallinn, 2004, 68-70.

40 Eesti külade ja väikelinnade liikumise "Kodukant” III Maapäev Hiiumaal Käinas 29.-31.7.1999. Dokumentide kogumik, 2-10.

41 Ibid., 30.

42 Åström, A.-M. What are the borders in a borderless society? - Studia Fennica Ethnologica. Making and Breaking of Borders. Ethnological Interpretations, Presentations, Representations. Eds. T. Korhonen, H. Ruotsala, E. Uusitalo. Helsinki, 2003, 31. 


\section{Voice - innovation groups}

According to Sztompka adaptive innovation involves all efforts aimed at improving the position of individuals or groups within incongruent and stressful cultural conditions. ${ }^{43}$ In Estonia, like in all Central and Eastern European countries, the previously unknown post-modern culture exerts a strong influence in the field of folk culture, thus resulting in rapid reshaping and renaming processes. In the heterogeneous representations and also in the new functions of folk culture we can see a mixture of Post-modern and Post-Socialist culture patterns.

In the minds of the practitioners a large-scale deconstruction of the former boundaries of folk culture is going on. A shift from the ancestors' heritage to today's grass-root level leisure-time interests is clearly evident. Folk culture is interpreted as a means of renewing traditional patterns of behaviour and thinking. It is a creative everyday experience of the ordinary people who reinterpret and present the richness of the past and demonstrate it, using a code that is understandable in modern society. This is in accordance with the general tendencies of the modern world, where tradition is being regarded as dynamic. In recent decades hybridity - a new postmodern species of authenticity - has come to be seen as positive and creative and less morally compromised than the "purity" and "authenticity" that rallied support so often in the past. ${ }^{44}$

Over the past decade resistance to incongruent and uncomfortable circumstances in national identity-formation has been increasingly resulting in a new innovative discourse and new modes of folk culture. We will examine some examples of the innovative trend as it is revealed on the levels of ideas and practice:

\section{a) new intellectual movements}

A brilliant illustration of the innovative use of folk culture is represented by the Genuine Culture (omakultuuri) movement. The main basis of this ideology is the Viljandi Academy of Culture and the groups united by the Heritage Music (pärimusmuusika) Festival. A similar approach to folk culture already started to take root in the 1970s and 1980s in relatively limited circles of intellectuals. ${ }^{45}$ The word itself has been borrowed from the rhetoric of the 1930s. Nowadays such an approach to folk culture still largely reflects a dialogue with professional culture.

The new animators see great value in their role as one of the mediators between professional and folk culture as well as between Estonian and world culture. Tolerance, openness and expertise in national heritage are valued in the first place.

43 Sztompka, P. Op. cit., 461.

44 O'Giollain, D. Tradition, Modernity and Cultural Diversity. - In: Dynamics of Tradition. Perspectives on Oral Poetry and Folk Belief. - Studia Fennica Folkloristica, 13. Ed. L. Tarkka. Tampere, 2003, 38.

45 For details see Kuutma, K. Changes in Folk Culture and Folklore Ensembles. - Folklore, 1998, 6. At http://www.haldjas.folklore.ee/folklore/vol.6/krifolk6.htm, 6 pp. 
Folk culture has to be genuine and improvisational, not aimed at an artificially stylized performance, but to arise as a natural result of creativity. ${ }^{46}$ Tradition is permanently recreated through individual interpretations. Individuals who combine different local and foreign influences, using cultural loans as sources for inspiration, transmit heritage. Ideologically this movement is clearly egalitarian and opposed to a competitive or hierarchical approach to folk culture.

Another example of an intellectual movement integrating the old and the innovative in folk culture is ethno-futurism. It is defined as an integration of elements from foreign material culture and technologies into an ethnically specific model of culture and local worldview without truly altering it. The basic idea is to blend the opposites in culture by integrating the native and ancient with the universal and ultramodern. This ideology acknowledges its preference of a postmodernist approach to folk culture and indeed to all cultural life - welcoming a meeting of the indigenous with the cosmopolitan and urban. The initiators of the movement themselves regard this ideology especially relevant at moments of identity crisis. ${ }^{47}$ Special emphasis is put on Finno-Ugric heritage and on active co-operation with intellectuals of Finno-Ugric origin. This idea is relatively unprecedented, although it is close to the views of some prominent Estonian intellectuals like Oskar Loorits ${ }^{48}$, Uku Masing ${ }^{49}$ or Jaan Kaplinski ${ }^{50}$. It has probably also been inspired by a romantic reinvention of the Finno-Ugric identity of Estonians that already began in the 1970s in music, art and film production. In contemporary Estonia, the movement has remarkably influenced the leaders of the South-East Estonian ethnocentric movements of Vorro and Seto that are engaged in the reconstruction and modernization of local identity.

Besides cultivating a more open and creative attitude to folk music, folk customs, traditional crafts etc., one of the main shifts in the attitudes towards folk cultural heritage has been about movement from collective to individual in the experiencing and presentation of tradition. The younger generation now considers individual "appropriation" to be not only a legitimate, but also a preferable way of interpreting folk culture. Compared with the previous decades, the private sphere - family, home and neighbourhood - are much more included in the folk culture of contemporary Estonia. Such an approach helps to reintegrate people into the local community.

46 See for detais: Joons, S. Sounds of Estonia. The Institutionalisation and Construction of Traditional Music at the Viljandi Culture College in Estonia. MA Thesis. Tallinn. Estonian Institute of Humanities, 2002.

47 Heinapuu, O., Heinapuu, A. Some treatments of the concept of ethno-futurism in Estonia. http://www.suri.ee/etnofutu/idnatext/ethno_en.html; Viires, P. The phenomenon of ethnofuturism in contemporary Estonian literature. - Congressus Octavus Internationalis Fenno-Ugristarum. Jyväskylä 10.-15.8.1995. Pars VIII. Litteratura \& Anthropologia. Moderatores. Jyväskylä, 1996, 235-238.

49 Masing, U. Keelest ja meelest. Ed. U. Sutrop. Tartu, 2004.

50 Kaplinski, J. Natsionalism ja ratsionalism. - In: Poliitika ja antipoliitika. Tallinn, 1992, 47-51; Kaplinski, J. Rahvalaulu juurde jõudmas. - In: Võimaluste võimalikkus. Tallinn, 1977, 143-183. 
The intellectual trends described above illustrate a wider tendency towards an ecological interpretation of folk culture: a strong accentuation of national territoriality, connection with the native milieu and domestic landscape. It is often emphasized that, while global culture is self-abundant, and acquires its identity through abstract, outward-projected ideas and values, local culture is directed towards its environment. This is considered to be an advantage, especially at moments that are critical for the preservation of a culture's identity; ${ }^{51}$

\section{b) new local practices}

The innovative attitude is characterized by an integrating approach to different aspects of the Estonian heritage. Another characteristic is a transfer from a nationcentered approach to folk culture to evaluating the national tradition in a global context. Often local cultural events unite the celebration of historical and ecological heritage. At the same time elements from the worldwide culture and global encounters are welcomed. Such processes are not unique to Estonia, but portray general tendencies. The German ethnologist $\mathrm{H}$. Bausinger describes this as follows: "While the exotic is no longer at the other side of a closed horizon, but is lived through inside the world that can be immediately experienced, and, on the other hand, the domestic is no longer restricted to one's own native space, the formerly opposing tendencies are united into a kind of Internal Exotic (Binnenexotik)". ${ }^{52}$

There have emerged various groups of NGOs, societies and courses in whose practices folk culture is surrounded by a wide zone that is open to dialogue with new economic and cultural spheres. Both co-operation and the maintenance of traditions are valued, but at the same time new means of communication and economic initiatives are integrated into local movements. For example, in Lihula, a small town in Western Estonia, the local Lions Club has introduced an event called Lihula Miil (coal-burning) that has already become a new tradition. Voluntaries keep old customs and traditions alive, animate a piece of history and, with the earned profit, support the cultural activities of children, for example, by presenting children with books or buying violins for the county music school. ${ }^{53}$

In Tartu county Regiöö (the night of regilaul, the ancient Estonian runic verse song, - A. K.), a festival of an archaic art, aims to introduce and teach older Estonian folk songs. It tries to offer people a chance to feel the power of their rich song heritage and to learn it in the natural way, i.e. by singing together. It offers a possibility to "through communal singing search for the internal peace and balance characteristic of the Finno-Ugric people". The slogan of the festival "Discover a singing-bird in yourself" ${ }^{, 5}$ illustrates the event's focus lying

51 Maran, T. Ecosemiotic Basis of Locality. Koht ja Paik II. - Eesti Kunstiakadeemia Toimetised, 2002, 77.

Bausinger, H. Volkskultur in der technischen Welt. Frankfurt; New York, 1991, 93.

http://www.hot.ee/lihulamiil/miil.htm

http://www.tartu.ee/rahvakultuur/regioo/1_est.html 
on individual experience and improvisation. The highlight of the festival was a simultaneous communal singing of an archaic runic song via the Internet. The precantor started in Viljandi and the festival audience joined in from Tartu, having real-time feedback on a large screen. Also, the program was available via RealVideo in the Internet. Future plans include extending the event to the whole Baltic region, so the Internet would be the medium that enables people to experience the older layers of tradition that exist in the region. The organizers aim at provoking a discussion in the society and want to promote innovative visions of the use of national heritage in the modern world.

These examples confirm the viewpoint of the American folklorist Alan Dundes, who argues that, instead of stamping the folklore out, technology is instead becoming a vital factor in the transmission of folklore, providing an exciting source of inspiration for the generation of new folklore ${ }^{55}$. Accordingly, it has become evident that in order to determine new processes of contemporary everyday culture, scholars also have to take into account modern communication media that gives life to these processes.

\section{CONCLUSION}

The collapse of Socialism in Eastern Europe provoked some turbulent social changes that, on the one hand, manifested in a traumatic loss of existing values, but on the other hand inspired the actors to generate novel attitudes and innovative practices. As the habitual value-constellation of the Estonians against the Kremlin authorities - the Singing Nationalism - found itself in a crisis, it became necessary to review the previous concepts of regarding folk culture as the main basis of nationwide protest. The Singing Nationalism as a mode of identity reproduction that functioned in a closed (totalitarian) society was inevitably bound to crumble as the society opened up.

For analyzing Post-Socialist intellectual disorientation the theory of cultural trauma is one of the most relevant approaches. Within this theory it is possible to systematically scrutinize the reasons for the unraveling of the trauma as well as the strategies used to cope with it. The present article relies on empirical material that consists of a collection of biographies (interviews conducted by A. Aarelaid, N72) and a series of focus-group interviews with some animators of folk culture (carried out in 1998, N14; 2003, N18). Over three or four generations there was a functional symbiosis of anti-Sovietism and folklorism. Today these are disconnected, which fact is now associated with the emergence of both inert and innovative trends. The need to cope with the traumatic loss of the $\mathrm{SN}$-identity has created a new vision of folk cultural activities, which is related with some fresh concepts concerning the Estonian national identity in the global era.

55 Dundes, A. Kes on rahvas? Valik esseid folkloristikast. Tallinn, 2002, 11-32. 


\section{RAHVAKULTUURI DÜNAAMIKA JA JÄTKUSUUTLIKKUS}

\section{Aili AARELAID-TART ja Anu KANNIKE}

Nõukogude ajal välja kujunenud rahvakultuuri struktuur ja tähendus alternatiivse rahvusidentiteeti kaitsva väärtussüsteemina kaotas oma baasi pärast Eesti riikliku iseseisvuse taastamist. Tegemist oli postsotsialistliku kultuurimurranguga, mis 1990. aastail muutis rahvakultuuri eksistentsiaalsed küsimused aktuaalseteks. Sihtfinantseeritava projekti raames läbi viidud analüüs kirjeldab viimase aastakümne rahvakultuuri dünaamikat: laulval rahvuslusel põhineva identiteedi kadumise järel kujunes uus nägemus rahvakultuuri mõistest, uued praktikad ning seeläbi ka uus arusaam rahvusidentiteedist üleilmastumise kontekstis.

Rahvakultuuri jätkusuutlikkuse tagamiseks tuli senine nn laulval rahvuslusel põhinev identiteedihoidmise mudel dekonstrueerida. Laulev rahvuslus kui rahvakultuurilise tegevuse põhiväli oli arenenud suletud ühiskonnas, ühiskonna avanedes tekitasid püüded seda säilitada aga kultuuritrauma situatsiooni, millest ei pakkunud väljapääsu ka lühiajaline nostalgilis-idealistlik nägemus rahvakultuurist.

Intervjuumeetodil kogutud materjali põhjal analüüsiti, kuidas väljendub toimetulek traumaatiliste muutustega rahvakultuurialases diskursuses. Kujunes paralleelselt kaks hoiakugruppi: soov jätkata traditsioonilise laulupeokeskse klubiliikumisega, teisalt ühiskonna kultuurilisest avanemisest, turumajandusest ja tarbimisühiskonnast ajendatud suund luua rahvakultuuri ümber uus funktsionaalne süsteem. Uuenduslikkus haarab enda alla paljusid senitundmatuid postmodernistlikke kultuurimõjusid. Postmodernistlike, postsotsialistlike (ja postkolonialistlike) kultuurimustrite segunemine avaldub innovatiivses diskursuses, uutes rahvakultuuri vormides ja funktsioonides. Toimub rahvakultuuri varasemate piiride laiaulatuslik lammutamine. Muutunud on ka suhtumine rahvakultuuri pärandisse, kus on toimunud nihe varasemalt, põhiliselt kollektiivselt kogemuselt, tõlgendamiselt ja esituselt individuaalsele. Varasemate aastakümnete rahvusliku vastupanukultuuriga võrreldes on tänapäeva Eestis rahvakultuur tunduvalt rohkem seotud erasfääriga - perekonna, kodu ja lähikogukonnaga. Selgelt väljendunud on ka suundumus rahvakultuuri väärtustamisele ökoloogilises kontekstis. Etnosekeskselt ideologiseeritud rahvakultuuri käsitluselt liigutakse rahvusliku traditsiooni nägemisele globaalses kontekstis ja lõimimisele globaalse kultuuriga. Selleks kasutatakse infoühiskonna uusi kommunikatsioonivahendeid (veebipõhine rahvakultuur), rahvakultuuriga seotud rohujuuretasandi aktiivsus on ka uuel viisil institutsionaliseerunud. Seega võib 21. sajandi algusaastail rääkida rahvakultuuri uue mudeli väljakujunemisest ning innovatiivse suuna domineerimisest rahvakultuurialases diskursuses. 